\title{
DINAMIKUS KÖVETKEZETLENSÉGEK ÉS AZ ÉRZELMEK SZEREPE A SZERENCSEJÁTÉKOKBAN
}

A napjainkban leginkább elfogadott definíció szerint az olyan magatartásváltozást nevezzük kóros játékfüggôségnek, amikor az egyén olyan viselkedési zavarban szenved, mely állandó és visszatéró problémát okoz az illetố szerencsejátékokkal összefüggő viselkedésében, és ezzel negatívan befolyásolja személyes kapcsolatait és hivatásbeli céljait (Demetrovics és tsai, 2009). A szerzó munkája elején röviden utal a kapcsolódó gazdaságpszichológiai elméletekre, majd néhány friss kutatási eredményt mutat be, amelyek lényegesek a korlátozottan racionális emberi viselkedés megértésében, illetve a fogyasztási preferenciák és az idôinkonzisztens döntések elôrrejelzésében (Andrade - Iyer, 2007; Rabin, 2008; Barkan - Busemeyer, 2005). A hivatkozott kutatási eredményeken felül az addiktív fogyasztói magatartás vizsgálatára további két kísérletsorozatot elemez. Végül saját kutatási eredményét mutatja be, amely rávilágít a szerencsejátékosok - dinamikusan inkonzisztens - döntéseinek hátterére: ma már szinte közismert, hogy a szerencsejátékos emberek önnön korábbi terveiket szegik meg, és azután többet tesznek fel a játékra, mint azt kezdetben megtervezték.

Kulcsszavak: idôinkonzisztencia, kilátáselmélet, pre-outcome feeling, post-outcome feeling, magatartásgazdaságtan

Mottó:

„,Vágyainkon kívül önmagunkból semmi sem érdekel bennünket, de vágyainkat nem mi választjuk. Vágyaink választanak és határoznak meg bennünket, és azon a napon, amelyen e vágyaktól megszabadulva felébredünk, nem gyózünk csodálkozni, hogy mit múveltek velünk.”

(Marcel Jouhandeau)

A gazdasági növekedés nem minden esetben vezet az életminőség javulásához: sôt, a gazdasági fejlődés sok helyen együtt járt a stressz emelkedésével, az életstílus gyökeres változásával, ami sok esetben kifejezetten pazarló, és nem egészséges fogyasztói magatartásban nyilvánul meg (Chopra, 2004).

A döntéselméleti alapiskola kezdetben a várható hasznosság klasszikus modellje mentén közelítette meg a döntéseket, amely a hasznosság mérhetôsége mellett lényegében annak nagyságrendje alapján volt képes valamiféle rangsort felállítani az egyes döntési alternatívák között. Fontos ugyanakkor megemlíteni, hogy már ezek a modellek is foglalkoztak a hasznosság és a kockázati attitúd kapcsolatával (Simon, 1979), annak különböző aspektusaival, ugyanakkor a várható hasznosság elve idôvel igen messzire, egy nagyon öszszetett, soktényezôs döntési térhez vezetett.

Kahneman és Tversky már 1973-ban bebizonyította - ellenôrzött kísérleti körülmények között -, hogy az emberek elôrejelzéseik és állításaik megfogalmazásakor rendszerint nem a várható hasznosság klasszikus modellje szerint járnak el; kockázatos vagy összetett döntési helyzetekben gyakran leegyszerúsítik a problémát, és szubjektíven hozzák meg döntéseiket.

Az elmúlt időben jó néhány közgazdász és pszichológus kísérelte meg modellezni a különbözó viselkedési anomáliákat, vagy mint pl. a kivetítési torzítást a jövőbeli hasznosság előrejelzésében (Rabin, 1998).

Jelen dolgozat írója szerint dinamikus környezetben kell vizsgálni a szerencsejátékot is, hiszen a tevékenység kórossá válásában jelentős szerepe van annak a ténynek, hogy a játék öröme, izgalma, és esetenként nyeresége időben megelőzi a kiszállásra való képtelenség 
miatt fellépó kudarcot és lelkiismeret-furdalást. Ezekre az érzelmi hatásokra olyan torzítások következnek be amelyek azt eredmenyezik, hogy az elore megterveze és az utólag megfigyelhetố, tényleges viselkedés köz különbségek lesznek, ezeket nevezi a szakirodalom dinamikus következetlenségeknek (Barkan - Busmeyer, 1999, 2003; Barkan, 2005).

„Az emberek alulbecsülik saját viselkedésük és a külsố tényező́k jövő́beli hasznosságukra vonatkozó hatását, és így túlértékelik jövớbeli és jelenbeli preferenciáik hasonlóságának mértékét”- - mondja ki Rabin renciálik hason a „Kivetútesi torzitás a jövốbeli hasznosságok elörejezésében" címúu munkájában (2002), ahol jól foglalja össze a megtervezett és a tényleges viselkedés közötti különbségek közgazdaságtani lényegét. Mindez a szerencsejátékra értelmezve a következő́t jelenti: (1)
tervezési fázisnál az egyének függetlenül kezelik mindtervezési fázisnál az egyének függetlenül kezelik mindegyik szerencsejátékukat egymástól, míg (2) a tényle-
ges szerencsejátékok alatt az eltéréseket változáskén ges szerencsejátékok alatt az eltéréseket változáskén (elôző eredmények függvényében) írják le, (3)

Adinamikus inkonzisztenciák a szervezetek életében és a menedzsment döntési mechanizmusában éppúgy tetten érhetőek, mint olyan „hétköznapi” helyzetekben, mint a szerencsejátékok. Elóbbi szituációkra a legtriviálisabb példa a tốzsdei ügynökök múködése és döntési álisabb ṕcta a tôzsci ló szisztémák, de a problénát megvilágíthatja a vállal tok eletében ujra felcrtékelódó 3-5 eves stratégiai tervek egymásra épulése. Ma már az ún. csúsztatott tervezéssel szinte folyanatosan módosíya a vállalatvezetés a hosszú távú elképzeleseit, mivel az új információ a vállalati elôzó eredmények ismeretében az eredmenyesség kritériumrendszere folyamatos irány(döntés) módosításokat igényel. A cikkben tárgyalt kérdések inkább az egyéni kisvállalkozókra érvényesek, illetve az olyan döntési helyzetben levő munkavállalókra, akik - mint tőzsdei befektetók és/vagy ügynökök - rendszeresen hoznak döntéseket, amelyek során viszonylagosan gyors a visszajelzés, és véletlenektól erôsen fügoó módon alakulhat a nagy nyereséget eredményező, vağ éppen nagy veszteséget okozó kimenet.

\section{Két kísérleti eredmény bemutatása}

E. B. Andrade és G. Iyer 2007-ben szerencsejátéko kísérleteket végzett laboratóriumi körülmények között, a résztvevớk két - egymást követố - szerencsejátékban vettek részt, melyek során megkérték óket, hogy tegyék fogadói terveiket elóző eredményeiktól függóve (,Mennyit fogsz feltenni szerencsejátékra, ha nyersz veszítesz az elsố játékban?’). A tervezési fázis után résztvevớk belépnek a tényleges fázisba, ahol megké- rik óket, hogy játsszanak és váratlanul megadják annak hetôségét, hogy felülvizsgálják az előzetes terveiket. A dinamikus következetlenségek a kísérlet során az alábbiakban nyilvánultak meg:

- amikor nyertek az elsô szerencsejátékban, az egyének kockázatkerülóbbé váltak, holott ennek egyének kockázatkerúlóbbé váltak, holott ennek az ellenkezójét várnánk, Delgado (2009)

- az eltérések a tervtól gyakoribbá válnak egy máaz eltérések a tervtól gyakoribbá válnak egy máeltéréseihez mérten).

A fentiekre Barkant és Busemeyert is talált bizonyitékot 2003-ban, a veszteségek és hasznok eltérő rekciót váltottak ki mind a következó játékban, mind a tervezettekhez képest.

\section{Dinamikus következetlenségek ${ }^{1}$}

A szubjektív valószínúségekben bekövetkezô változások közül mindkettô (nyertes, vesztes) következetes abban, hogy a szerencsejáték-résztvevók a tényleges fázis alatt azt tervezik, hogy többet kellene feltenniük, mint a megtervezett veszteség, és kevesebbet, mint a megtervezett haszon.

A fentebb említett kísérletben (Andrade - Iyer, 2007) 135 diák vett részt egy számítógéppel szimulált játék-

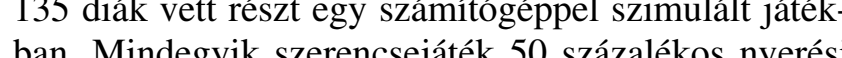
ban. Mindegyik szerencsejáték 50 százalékos nyerési esélyre volt programozva, azaz 50 százalékos esély A résztvevók 15 dollárt elveszítse a fogadását.

A résztvevók 15 dollárt kaptak a kísérletben való részvételükért, vagy ezt tették kockára a kísérletben. A kísérlet kezdetén mindenkinek lehetôséget adtak fogadásaik megtervezésére, továbbá, hogy egy elôzetes játékban (tét nélkül) megismerhessék a játékot. A tervezési fázisnál a résztvevớk azt hitték, hogy kijelentetttervezett fogadásaikat ténylegesen lejátsszák, annak összegszerúségén már nem változtathatnak.

A kísérlet során, a tényleges fázis alatt, hogy elkerüljék az esetleges információvesztést, emlékeztették a játékosokat a megtervezett fogadásaikra így bármelyijâtekok a mes in kük feluul tudta vizsgálni a

5 perc után a játékosok megismerték elért eredményüket, és újabb fogadásra volt lehetőségük. A résztveớk felírták az elért eredményt egy ún. pénzügyi nyilaantartásra, amit arra használhattak, hogy kiszámítsák végsố részvételi díjat, mivel a végsô megtett tét változatható volt (5 dollárról 25 dollárra).

A játék során 20 világos és 20 sötétszürke négyzet jelent meg a képernyő́n (lásd függelék 1). Egy $\mathrm{X}$ jel véletlenszerúen villant a táblán 15 másodpercenként.
Mindegyik villanás független volt az előzótól. A játék végén a villogás megállt. Ha az $X$ jel egy sötétszürke négyzetben állt meg, a résztvevő megduplázta a felte tétjét; különben elvesztette a fogadást. A nyertesektó azt kérték, hogy emeljék fel a kezüket - jelezve, hogy nyertek vagy veszítettek -, úgyhogy a kísérletezó kétszer ellenőrizhetett minden eredményt. Ez az eljárás lehetôvé tette azt is, hogy minden résztvevő egyszerúe ellenőrizhesse, megfigyelje a nyereségek és veszteségek tényleges elosztását a szobában. A kísérlet során az tapasztalták Iyerék, hogy a veszteségek a résztvevók tapkedvetlenítették a következő szerencsejátékoktól, mík elkedvertéc ra, amit a következó szerencsejátékokra feltettek.

A dinamikus következetlenségek aszimmetriája

Elôször - az egyének úgy gondolkodnak, hogy h vesztenek, utána kevesebbet tesznek majd fel, az elózó fogadással összehasonlítva. Ez a jelenség azt mutatja hogy az egyének nem szükségképpen hagyják figyelmen kívül az előzố eredményt, amikor megtervezik következő fogadásukat.

Az emberek a korábbi játékuk során elért eredményeiket a következő fázisnál integrálják viselkedésükbe, azaz az első eredményt nem hagyják figyelmen kívül a második tervezésében. A veszteségek a résztvevóket arra késztetik elvileg, hogy kockázatkerülóbb váljanak.

Összegezve Andrade-ék kísérleti eredményeit: a megtervezett és tényleges fogadások eltérte egymástól,

- a résztvevók átlagosan többet fogadtak, mint kezdetben megtervezett, de

a tervezett és tényleges költést befolyásolta az elért eredmény (nyert vs. vesztett).

A nyereség-veszteség aszimmetria

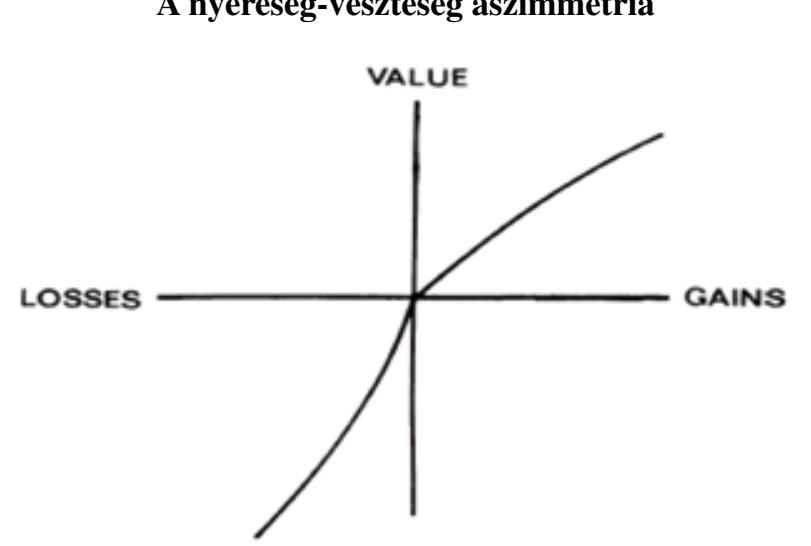

Forrás: Kahneman - Tversky (1979)
A kísérleti eredmények tökéletesen igazolják a Prospect Theory-t (Kahneman - Tversky, 1979): ez az ábrán látható, ma már klasszikusnak számító elmélet a bizonytalanság mellett mutatja be a várható hasznosság klasszikus elméletének kritikáját a döntéshozatal leírô modelljeként, és kifejleszt egy alternatív modellt, melyet kilátáselméletnek nevezünk (Kahneman - Tversky, 1979). A választások (döntések) bizonytalan kilátások között több olyan hatást váltanak ki, amelyek ellentmondanak a neoklasszikus közgazdaságtan alapvető tanainak. A különbözô alternatívák ugyanakkora várható értékei mellett eltérón döntenek péld́́l, ha olyan kimeneter a kváni a kvázi biz sosakkal összehasonlitva. A bizonytalanság hozzáj hizlo kockáz ószentléshez azokban a valasztásokban, amelyek biztos haszonnal járnak (ahol van biztos haszonnal járó kimenet), és kockázatra ösztönöz azon választásokban, amik biztosan veszteségekkel járnak (illetve az olyanokban, ahol a kimenetek veszteségekben vannak megfogalmazva). Mindezen túl megfigyelhetố, hogy a döntéshozók általában olyan összetevớket hagynak figyelmen kívül, amiket jó néhány döntéselméleti vizsgálat igazol: a figyelmi kapacitás szúkössége következetlen preferenciarendezéshez vezet, ezt nevezzük izolációshatásnak (Kahneman, 1973).

A kilátáselmélet alapján felvázolható értékfüggvény nyereségek esetén rendszerint konkáv, veszteségeknél konvex, és veszteségeknél általában meredekebb, mint nyereségeknél. A nagyon alacsony valószínúségi tartományban a kis valószínúségeket túlbecsüljük, míg a magas valószínúségeket alulbecsüljük. A bizonyossági hatás szerint pedig a nagyon magas valószínúségeket biztosnak vesszük. Az alacsony valószínúségek ugyanakkor hozzájárulnak a szerencsejátékok vonzerejéhez (Johnson et al., 1993). Jelen dolgozat szempontjából ez utóbbi megállapításnak azért van jelentősége, mert ez alapvetően ellentmond a klasszikus megközelítéseknek, ugyanakkor alátámasztja a szerencsejátékok kapcsán jól megfigyelhetố pszichológiai hatást, amely így mégis összekapcsolhatóvá teszi a valószínúséget és a jútékot, illetve annak soŕ́t A kapocs a megét érzelmek átal kiváltott szubjektív torzít́s, amely dinamikus következetlet szubnyilvánul meg. A játék közben megélt érzetenségben kiemelt szerepet kap a csalódás és a szomorúság.

\section{A dinamikus kovetkezetienségek okai,}

az érzelmek szerepe

Az izgalom a hazardírozás mértékével arányosan nố Blaszczynski - Wilson - McConaghy, 1986; Caplin Leahy, 2001; Conlisk, 1993; Dickerson, 1993; Griffins, 1995; Johnson - O’Brien - Shin, 1999; Pope, 1983). 
Ha az érzelmek szerepét szeretnénk kimutatni és felmérni, erre a bemutatott kísérletek azon fázisa nyúj lehetőséget, mely során a játékot megelőzően és közvetlenül a játékot követően is mérjük a résztvevő́k ézelmi állapotát. A fentebb említett kísérletsorozatba elôbb egy bipoláris skálás megkérdezéssel (szorongás és izgalom a két szélsőérték), majd egy koordinát tengely mentén kellett érzelmi szintjüket bejelölni, mivel egyszerre lehet valaki izgatott és ideges (lás függelék 2).

A témában legfrissebb publikált kutatásban (Jeffrey A témában legfrissebb publikát kutatásban (Jeffrey tott/tapasztalt viselkedés hatását vizsgálták szerencsejáték során. Korábbi kutatások kimutatták, hogy az elért eredmény - fóként a veszteség - inkább növeli kockázatkeresố magatartást, a nyeremény inkább csökkenti (pl. Delgado, 2009). A kérdést egy új aspektusbó vizsgálták meg Jeffreyék: hogyan változik a viselkedés, amikor az összes eredmény eléri vagy meghaladja a várakozásokat?

Feltételezték, hogy ennek oka a viszonyítási pont, melyet tompíthat a csalódás és a szomorúság. Ebbe az esetben, összehasonlítva a játékban elért nyereményeket: az alacsony eredmény kevésbé negatív értékelést eredményez a résztvevốkben, mint a magasabb. A pozitív értékelés ellensúlyozza néhány kis eredón A poziliv étécelés ellensúlyozza néhány kis eredmén

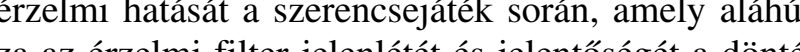
za az érzelmi filter jelenlétét és jelentőségét a döntés jelyzetekbenen, különösen az egy

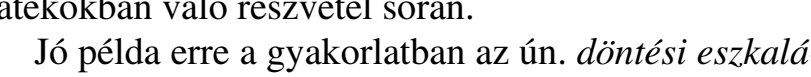
ció jelensége, amikor a gazdasági szervezetekben me hökkentóen gyakran az egymás ellen játszó döntéshozók úgy emelik folyamatosan a „tétet”, hogy világosa látszik: ebbő́l a versenyból legalább az egyik, de gyakran minkét fél óriási veszteséggel száll majd ki.

Más döntéshozatali elméletek is figyelembe veszik a kockázatkereső/kerüló magatartást. A korai várható hasznosság elméletek szerint a kockázati preferencia a hasznossagi függvény különbőzổ részein változik (Friedma Savage szerint a különböző szintú jólét váltakozó kockázatkerülést és kockázatkeresést eredményez.

Markowitz már korábban (1952) javasolta az eredMarkowitz már korábban (1952) javasolta az eredményeket aszerint értékelni, ahol a referenciapont vátozik, az értékfüggvény konvex kis nyereség es

Jeffreyék arra utalnak, hogy a pszichológiai eredmények többrétúek annál, mint a referenciapont megtalálása és értékelése: megítélésük szerint kutatásuk következménye az, hogy túllép a pszichológia a kilátáselméleten. Egy érdekes kiterjesztési szempont, hogy vannak más potenciális tartalékok a kockázat kezelésének elemzésében: például a munkatárs vagy a versenytárs is lehet kvázi viszonyítási pont, befolyásolja gyanis pl. a teljesítményszintet (Jeffrey et al., 2010)

Tanulmányuk lényege, hogy az alanyok vajon hajandóak-e kockázatot vállalni, amikor mindenféleképpen elérik céljukat? Valamint, hogy mennyire határozza meg a cél azt, hogy azért mekkora kockázatot képesek vállalni? Kísérletük során kétféle változatot találtak:

- ha az alany tisztában volt azzal, hogy mit is akar elérni, akkor sokkal inkább vállalt kockázatosabb dolgokat

viszont mikor az alanynak nem voltak tiszta céljai, sokkal inkább elkerülte a ,veszélyt”, és inkább a biztosabb utat választotta.

A hivatkozott kutatásokban azt vizsgálták, hogy a döntéshozók mennyiben hajlandóak kockázatot vállalni az összes lehetséges kimenetel függvényében. Két vizsgálatban mutatták be, hogy a kockázatvállalási hajlandóságot hogyan növeli az elérhetó eredmény. Azt találták, hogy ha jelen van bármilyen cél, akkor annak várható nagyságától függő́en a döntéshozók inkább vállalják a kockázatos választást nagyobb valószínúséggel, minthogyha nincsen biztos kimenetel, illetve kisebb a nyeremény. Ha nincs cél, inkább jellemzôvé válik a döntéshoźk kockzzakerḯre. Feltételezik, hogy enn és a fajo és a fajdalom is befolyásol. Ebben az összefugggésben, osszehasonlitva egy szerencsejátek alacsony várható eredményét, kevésbé értékelik negatívan a játékosok.

\section{Érzelmek a játék kimenetele elótt}

(pre-outcome feelings)

A legtöbb szerencsejáték-tevékenység esetén késleltetés van a fogadás és annak kimenetele között. Egy ember hasznossági függvényébe beépíthetốk a várakozásból fakadó pozitív és negatív érzések. Loewenstein 987-ben kimutatta hogy a negatív dolgot (enyhe ektrosolk) azonal akarják a vizsǵltak, de pl. a kedpl. a kedve

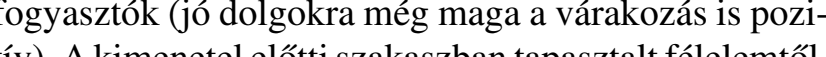

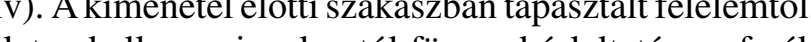
illetve kellemes izgalomtól függ a késleltetés preferált foka. A közgazdászok és pszichológusok felismerték a örömteli várakozást a legtöbb szerencsejáték esetéen (Griffiths, 1990, 1995). Mint ahogyan az étel hasznossága sem csak a tápanyagától függ, a szerencsejáték hasznossága sem csak a meggazdagodás miatt fontos. Az izgalom foka korrelál azzal, hogy ki, milyen erôsen (állhatatosan, szívósan, kitartóan) játszik. A szubjektív riportok szerint, a kísérleti alanyok között a szerencsejátékos tevékenység egyik legfontosabb motívuma az zgalom (Becker - Murphy, 1988). Például az ötös lottónál nem változtatható tét, játékszám, nem annyira dîrekt az élmény, nincs ráhatásérzés - míg puttó, tippmix esetén az izgalom jelentôs szerepet játszik.

A szerencsejáték folyamatában - a fent említett tanulmány szerint - résztvevő́k esetén a kimenetel elótti izgalom változhat a fogadások alatt, és a megtett összeg izgalmi hatást indukál. Pl. ha valaki úgy gondolja elôre, hogy a játék izgalmas lehet, akkor lehet, hogy többet

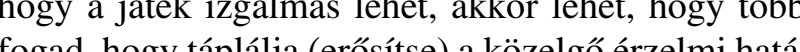
ogad, hogy táplâja (erositse) a kozzelgó érzelmi hatást. A tervezési fázisban az elôzzetes izgalom hasznosság megmagyarázhatja a potenciális elteréseket a tervtố tervezesi fázisban - mivel a fogyasztók még nem tapasztalták meg a fogadás sorrendjét - figyelmen kívi hagyhatják vagy minima lizálhajk a fogyasztás mértekét (alulbecsülik ezt az izgalmat), és nem foglalják be a tervezett fogadási döntésekbe. Azonban amikor eljö a játék ideje, és fóleg miután megtapasztalták az elso szerencsejáték során érzelmeiket, akkor a tevékenységgel kapcsolatos izgalom vagy idegesség feltúnővé válit és eltérésekhez vezethet az azt követő fogadások megtervezésében. Éppen ezért a második fogadás elôzetes izgalmi fázisának ideje alatt egyértelmú eltérések mutatkoznak. ( Ez a szerencsejáték sokkal izgalmas mu mint gondoltam, úgyhogy többet vagyok hajlandó fizermint érte!")

Negatív eltérések is tapasztalhatók a tervtől, ha a játékos erôs idegességet tapasztal a játék során. („Ez a szerencsejaték sokkal stresszesebb, mint gondoltam ezért csökkentem a fogadásaim tétjét, hogy elkerüljer a negativ érzéseket!")

Az eredményekben tapasztalt ellentmondásokat úgy is értelmezhetjük, hogy magas szintú izgalomnak ke következnie, ha a résztvevő úgy döntött, hogy pozitív irányban tér el a tervtốl a második fogadása eseté (mint ahogy az 1. kísérlet is ezt mutatta az 1 . fogadási veszteség után). Más szóval: a pozitív eltérések - leg alábbis részben - a résztvevớk azon szándékát jelzik, hogy „,megvegyék a következő izgalmi szintet” a 2. fogadás előfázisában

\section{Kimenetel utáni érzelme}

(Post-outcome feelings; hideg-meleg empátiarés)

Egy viszonylag semleges érzelmi állapotban az egye neknek nehezen tudják megjósolni, hogy hogyan éreznek és/vagy viselkednek majd egy erősebb belső fe fokozott (meleg) állapotban. Eme logika azt jósolná, hogy amikor egy adott dologtól megfosztiák az embert, akkor igyekszik visszaállítani az eredeti állapotot (ho- meosztatikus állapotot). Ez a „hot-cold empathy gap”, azaz a forró-hideg állapot közti különbség. Ez megmagyarázná, hogy az êhes fogyasztók miert vesznek oubb ételt, mint azt kezdetben tervezték (Gilbert - Gill - Wilson, 2002; Nisbett - Kanouse, 1968), vagy azt, hogy a kíváncsi egyéneket miért érdekli több a hiányzó információról, mint a kezdetben jövendöltek, vagy a kábítószer-élvezók miért becsülik alá a sóvárgás hatását. Bár az embereknek van alkalmuk arra, hogy tartsák az elóelkötelezettségeiket (vagy leálljanak), a tapasztalati bizonýték azt mutatta hogy az emberek általában átesnek a ló túlú oldá́r anak érdekébe kikeriiljenek az aktuális állapotból. Ételtól, azen, hogy ciról, dogot információtôl, drogoktól vagy a pénztól megfosztott egyének vicen visszaálítsák az elôzó állapotot. A szerencsejátékos kontextusban ez azt jelenti, hogy a veszteségek által generált negatív érzelmek miatt az emberek késztetés ereznek arra, hogy túlfogadjanak (pozitívan térjenek el az eredeti tervtốl) azért, hogy visszaállítsák a „nyerô" érzelmi állapotot.

A tervezési fázisban (mielôtt a kimenetelét megtapasztalhatták) az emberek alábecsülik, hogy az aktuális negatív érzéseik mennyire fogják befolyásolni ốket abban, hogy „kergessék a veszteségüket” abban az érelemben, hogy pozitív irányban térnek el a tervezett összegtôl.

\section{Kiból lesz függó?}

Dr. Demetrovics Zsolt (2001) vizsgálata alapján például a drogokat használókat, illetve kipróbálókat a nem használókhoz viszonyítva inkább jellemzi az élménykereső magatartás. Ertelmezésében a táncos szórakozóhelyeket látogató fiataloknál maga a droghasználat nem a hangulat befolyásolása érdekében történik, hanem a droghasználat mint izgalmas, új élmény keresése miatt jön létre. Ugyanakkor kutatásai során számos hasonlóságot talált a drogfogyasztók és a szerencsejáték szenvedélybetegek motivációja és viselkedése között. További intraperszonális hajlamositó tényezók között tartják számor e lamot, az agressziót, a gyenge önkontroll képessége-

Az empirikus kutatások szerint egyes csoportok jobban ki vannak téve a függő́vé válás veszélyének, mint mások. Ilyenek például a családi, munkahelyi problémákkal, vagy valamilyen pszichológiai gonddal küzdók (Ipsos, 2009-2010). Ám az is lehetséges, hogy ezek a eltételezett okok inkább a függőség következményei. Egy másik elmélet szerint azok válnak függő́vé, akik nem veszik komolyan a függő́ség kialakulásának ve- 
szélyét (Loewensein, 1996; Slovic, 2001; Elster, 1997). A zsigeri tényezók elmélete (Loewenstein - Elste 1992) is úgy tekint a függőségre, mint ,,a jövőbe vágyódás mértékének fel nem ismerésére". Ez utóbb elmélet szerint is vannak olyanok, akik jobban ki vannak téve a függővé válásnak. Ilyenek elôször is azok az egyének, akik vagy azért kezdenek drogokat fogyasztani, mert azt önmagában élvezetesnek tartják, vagy társadalmi nyomásra, vagy mert valamilyen elfojtott vágya elégítenek ki. Másodszor, ha az ismételt drogfogyasztás valamely külső környezeti tényezôhöz is kötődik. Ha valamely külsô kônyezeti tényezôhōz is kötôdik. Ha madszor pedig, ami egyben a zsigeri tényezók elméletének igazi különlegessége, hogy ha az egyén alábecsüli tényezó mindegyike illik, az nevezhető függósségre hajlamosnak a hivatkozott elmélet szerint.

\section{Konklúziók}

A dinamikus inkonzisztenciák véletlenszerúen függne az elózetes izgalmi vagy stresszérzésektôl. Azoknak kell megtapasztalniuk a legmagasabb szintú izgalmat vagy a legalacsonyabb szintú aggódást a fogadás alatt, akik a második fogadásuknál pozitívan térnek el a tervïktól (azaz leginkább, akik veszítettek az első fogadásnál) (Andrade - Iyer, 2007).

$\mathrm{Az}$ aszimmetrikus dinamikus inkonzisztenciák a forró-hideg empítia közti különbségból erednek, azaz

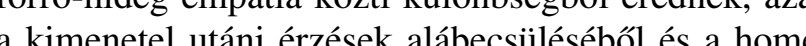

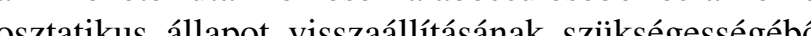
(az első fogás visszán (azk töbou foll" fogatese utan), ezét a resztvevóknek többet ,,kell” fogadniuk, mint akkor, amikor „,szabadon" dönthetnek.

Ha valakit határozottan utasítanak arra, hogy kontrollálja a kimenetel utáni érzéseinek hatását, akkor veszteség utáni pozitív eltérések csillapíthatók, és ennek következtében az aszimmetrikus dinamikus inkonzisztencia mértéke csökkenhet, szélsőséges esetben megszúnhet, annak alapján igazolva látom Demetrovics korábban meghivatkozott állítását, amely az addikciók esetén jelentő́s szerepelt tulajdonít többek között az önesetén jelentőss

Damasio szomatikus markerekkel kapcsolatos szerencsejátékos kísérleteiben arra a következtetésre juto hogy azon tesztszemélyeknél, akiknél a másodlagos érzelmek jelei nem mutatkoznak (illetve ezek hiányoz nak), nem viselkedtek racionálisan (Damasio, 1994). Lehetséges, hogy a szomatikus markerek „feltérképezése" rávilágít az addikciós betegségre, vagy már elózetesen az arra való hajlamra? Ha feltesszük, hogy vizsgálatokkal beazonosítható a szomatikus markerek korlátoltsága vagy hiánya, felmerül a kérdés: mekko- ra valószínúséggel fog ez az addikciós betegségekkel korrelálni? „A szomatikus markerek a másodlagos érzelmek által generált érzések sajátos esetei. Ezeket az érzelmeket és érzéseket tanulás révén összekapcsoltuk bizonyos szcenáriók elốre jelezhető jövő́beni kimenetével. Amikor egy negatív szomatikus jelölő együtt jár egy bizonyos jövő́beni kimenettel, a kombináció vészcsengóként múködik. Ha ehelyett egy pozitív szomatikus markert kapcsolunk össze a dologgal, ez vonzerőjelzés lesz" (Damasio, 1996:174. o.). Antoine Bechara és a Damasio házaspár az Iowa Egyetemen új kísérlet felfedét éter viselkedésmintákon vizsgálják az ên a páciensek, akiknek mindkét oldali frontális kéreg sérült volt, egy adott döntési feladatot (amivel egy pénzügyi veszteség kockázatát kellett mérlegelni), sokkal rosszabbul oldottak meg, mint a normális tesztszemélyek, illetve azok a tesztegyének, akiknél az agy más területein volt múködési zavar.

Ezeknél a pácienseknél úgy tűnt, hogy nincsenek érzelmi reakcióik - ezt a bő́r vezető́képességének mérésével állapították meg - mielőtt egy kockázatos döntést hoznak. A kontrollcsoport tesztszemélyei erôs érzelmi reakciót mutattak, mielőtt kockázatos alternatívákat választanak. Ezeket az érzelmeket értelmezhetik olyan figyelmeztetô jelekként, amik a veszélyes döntések elótt jelentkeznek. Mivel a sérült frontális kéregérzelmeket, hiányoznak ezek a figyelmeztetó jelek, és a felhalmozódó pénzügyi veszteségek ellenére sokkal magasabb arányban hoznak kockázatos döntést. Mindazonáltal a várható veszteségekre való érzelmi figyelmeztetổ jelek hiánya nem mindig akadálya az optimális viselkedésnek - ső́t elősegítheti azt (Fehr, 2005).

$\mathrm{Az}$ olvasóban felvetốdhet a gazdasági egyén, és a szerencsejátékos személy pszichológiájának kapcsolata a sokat kutatott „delayed gratification” jelenséggel és az önuralommal. A PNAS-ben jelent meg egy érdekes kutatási eredmény tavaly, amely a gyermekek önuralomra való képességének hatását vizsgálta nagy mintán és hosszú évtizedeken keresztïl, és mutatta meg miz̈̈nuralombar az egýn sikesśǵ, és nutatta meg az ônura

\section{II. kísérlet}

A második kísérleti szakaszban megpróbálták Iyerék megismételni az előzó eredményeket, és bizonyítékoamikus inkonzistenciával kapcsolatos érzések szerepére, valamint kifejezetten a veszteségek utáni pozitív érzelmi eltérésekre. Így a kísérleti folyamat nagyon hasonlított az előzóhöz a következő változtatásokkal:

VEZETÉSTUDOMÁNY
Először is egy skálát alkalmaztak, mellyel a résztvevốk felét a második fogadás ún. „érzelmi alapú vếleménynyilvánításra" (McFarland et al., 2003) kérték. Azt feltételezték, hogy ebben az esetben - a kontrollát állapothoz hasonlítva, a veszteségek után - az elốre e tervezett fogadás mértékétól való pozitív eltérés csillapítható (visszafogható). Szintén fontos, hogy mive nyereség után általában nem volt lényegi eltérés érzelmi skálájukon, az ,affective correction” (érzelmi korrekció) hatása úgy várható, hogy lenullázódna ebben az állapotban (Gilbert et al., 2002)

Másodszor, bevezettek egy in situ ,izgalmi-ide", ahol a résztvevóket arra kérték, hogy folyamatosan jelentsék érzéseiket mindegyik fogadás elôzetes periódusában.

Ez a megoldás lehetôvé teszi, hogy megtudjuk: az egyének fogadásainak mértékét a második fogadás eseté belsóleg facilitálja az elkövetkező izgalom vagy idege ség, avagy ez csak egy „mellékterméke” a szerencsejátekos tevékenységnek, mely nincs hatással a fogadásokra. Miután a résztvevő́k pozitívan vagy negatívan eltértek az előfázisban elérttőll, az izgalomnak magasabb vagy alacsonyabb szintünek kell lennie a második fogadásban tervezetthez képest (azért térnek el az emberek az eredetileg tervezettól, mert az izgalom hatáś vagy azért idegesek, mert az eltérés feszülltséget generál?).

\section{Kritika}

Bár a vizsgálati módszer a fent bemutatott kísérletekben nem teszi szükségessé a reprezentatív mintát, ennek hiányában azonban a ksé a reprezentatív mintát, ennek tartáskutatók számára relevánsak lehetnek, felvethetik a kérdést: az egyetemisták a legmegfelelóbb ,vizsgála alanyok"? Fontos szempont, hogy az alanyok nem a sajât pénzüket kockáztatták, ez pedig a döntési mechanizmusukat érdemben befolyásolhatta. Bármely pénzben játszott szerencsejáték esetén szignifikáns különbség mutatkozik, attól fügoóen hogy az egyének saját pénzïk teszik fel a jétćk soŕn, vagy , könnyen jütt” forinúk

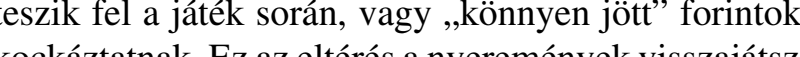

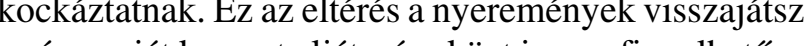
a és a sajáá kereset eljátszása közt is mégfigyelhetổ, sôt a patológiás játékfüggő́k és a normál játék

Rachel Barkan és társai 2005-ben publikált kísérleRachel Barkan és társai 2005-ben publikált kísérletükben bizonyítják a dinamikus inkonzisztenciát min
,elfogultságot” a késóbbi tervezés során: a döntéshozók nem követték tervüket csupán azért, mert a tapasztalt eredmények elterrtek attól, amelyekre a terv alapja számítottak volna. Pontosabban, miután megismerték a nyereségüket egy kísérleti hazárdjáték során, a dön- téshozók elutasították a második szerencsejátékot. A másik mintában a veszteségek hatását vizsgálták. Meglapításuk szerint a kezdeti eredmények módosítják a további tervezett választásokat, és tapasztalataikat integrálják további döntéseikbe. A kísérletből származtatott számítási hipotézis szerint az elôzetesen elért eredmények a tervezési szakaszban csökkentik, míg a dinamikus inkonzisztencia növeli az eredetileg tervezetthez képest a játékra szánt összegeket. A hivatkozott Kísérlet alapján levont következtetés szerint a megtervezett döntésekben az előzetes eredmények indukálják dinamikus inkonzisztenciát, mely fennall mindját y fennáll mindkét feltétel (nyereség-veszteség) esetén. Ezzel egy alterákra, és kapcsolatot találnak a becsült és a tényleges preferenciák között (Barkan et al., 2005).

\section{Összegzés}

Az aszimmetrikus dinamikus inkonzisztenciák jól megfigyelhetók és tanul tevékenységben. Mindez kiemelkedô lehetôsséget kínál arra, hogy jobban megértsük a fogadói magatartás „deformitását", különös tekintettel arra az esetre, ha ez már a túlzott szerencsejátékhoz és addikciós problémákhoz vezet. A fentiek alapión érthetôvé válhatott, hogy miért játszanak egyre többet a vesztesek, mint ahogyan

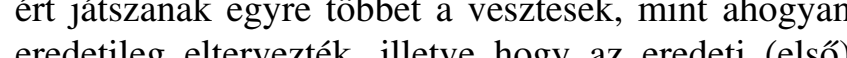
fogelis eltertek, illetve hogy az eredeti (elso) fogadási eredmeny hogyan befolyásolja a másodikat. A szubjektív valószinúnségek változása alapvetóen befo-

Bebizon mire és nonnil fog fogadni a játékos.

Bebizonyosodott Andrade és Iyer kísérletei által, hogy a tervezési fázisban az emberek alábecsülik, hogy a negatív érzések mennyibe befolyásolják óket a jövő́beli cselekedeteikben (döntéseikben), kvázi „mennyibe fog ez nekik kerülni

Ugyanakkor vizsgálatra érdemes terület a játékosok által megélt stressz és frusztráció, valamint az unalom szerepe a játékszenvedély-beteggé válás folyamatában, ezenfelül lényeges a társas kapcsolatok befolyása aḱ a leszoktáśs, áć az addiktívvá válás aspektuábót. Végül a szerenc jútćkosoka hást gyakón é

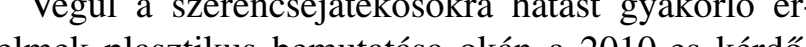
zelmek plaszalius bennutása okán a 2010-es kérdóives kutatson releváns részeredmenyét mutatom be, melyet játékfüggók körében folytatok. A felmérést anonim szerencsejátékosok (GA) körében végeztem, a felmérésben résztvevốk átlagéletkora 38,2 év (22 a legfiatalabb, 55 éves a legidôsebb válaszadó). A válaszokból kiderül, hogy az érzelmek (tehát a rövid távon ható, általában konkrét cselekvésben megnyilvánuló, látható érzelem) milyen hatást gyakorolnak a játékosra, és így a játék során véghezvitt döntési sorra is: 
- a válaszadók fele elégedett az életkörülményeivel, a nyereménnyel kapcsolatos információ nem annyira motiváló a kitöltók számára: 50\%-ukra nincs hatással,

a válaszadók több mint fele feszült hangulatban nem játszik annyit, mint szeretne,

korlátozott játéklehetôség esetén a válaszadók fele nyugtalan, illetve izgatott,

- ha játék közben veszítenek, a játékosok nagy része fokozza költését, de 75\%-uk biztosan újra játszik,

- a kérdốv kapcsán láthotó, hogy a játékfügogók ke-

vésbé feszültek játék közben (63\%),

- a válaszadók $75 \%$ boldogabbnak érzi magát játék közben, ezzel összefüggésben inkább rossz érzés tölti el ók a játék végeztével.

A felmérés konklúzió ja az is, hogy önmagában maga a játék (annak folyamata, léte, az abban valo részzétel) nagyon fontos a játékfüggó́k számára, közbeni nyereményáramok jelentősége nem annyira jellemzó (2. ábra).

A megkérdezett játékfüggók fele tesz erófeszitéseket annak érdekében, hogy kevesebbet költsö szerencsejátékra, en enére még többet jútsz

\section{Lábjegyzet}

and segregation on dynamic inconsistency. Journal of (16, iss. 4 , p. 235-255.

Damasio, A.R. (1996): Descartes Error - Emotion, Reason and the Human Brain (Descartes tévedése - Erzelem, Aderaba

F. (2005): Mit Neuroökonomik das menschliche Wesen ergrunden Nach der Psychologie ziehen Zïsthate. Neue Zurcher Zeitung, No. 146.

, M. - Savge, L.J. (1948): The utility analysis of risk. Journal of Political Economy, 56, p. 279-304.

A függók és az átlagos játékosok összevetése

a játékra költöttt összeg tervezettsége alapjân

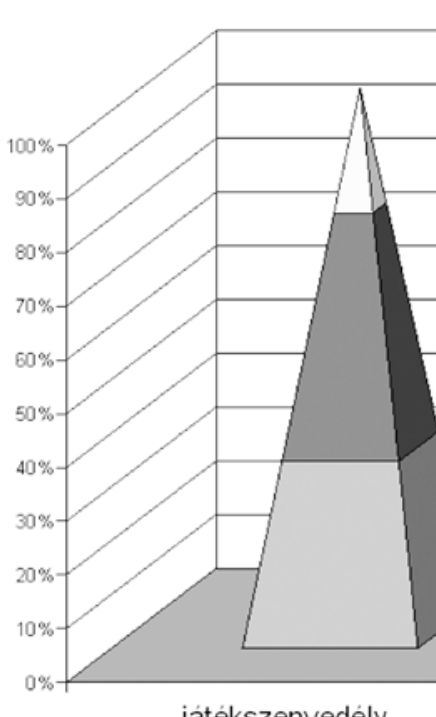

jatékszenvedély

A nemzetközi szakirodalomban „,inkonzisztencia” kifejezés terjedt inkább el, de megvan a magyar nyelvúu megfelelójje. irányultságát, fóleg gazdasági döntések esetében. Loewnstein: negatív érzésekre szúkítem a figyelmet, mert hatásuk hasonlít olyan ösztönző hatásokhoz, mint az éhség és az olyan érzelmi hatásokhoz, mint a fájdalom. A pozitiv érzések hatásai sokka komplexebbek és kifinomultabbak." (2000)

\section{Felhasznált irodalom}

Andrade, E.B. - Iyer, G. (2007): Dynamic Inconsistencies in Gambling and the Role of Feelings. Haas Business School Working Paper

Barkan, R. - Busemeyer, J.R. (2003): Modeling Dynamic Inconsistency with a Changing Reference Point Framing reference points: the effect of integration
McFarland, C. - Whiteb, K. - Newth, S. (2003): Mood acknowledgment \& correction for the mood-congruency bias in social judgment. Journal of Experimental Social Psychology, 39, p. 483-491.

Moffitt, T.E. - Arseneault, L. - Belsky, D. - Dickson, N. Hancox, R. - Harrington, H.L. - Houts, R. - Poulton, R. - Roberts, B.W. - Ross, S. - Sears, M.R. - Thomson, .M. - Caspi, A. (2010). A gradiest of child control predicts healh, wealh, and public saley. PNAS WW. R.E. Ka

Nisben, R.E. - Kanonse, D.E. (1969). Obesily, Food

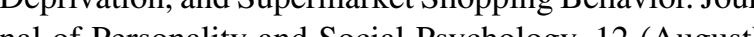
p. 289-94. p. 289-94.

O'Donoghue,T. - Rabin, M. (2003): Projection Bias in Predicting Future Utility. Quarterly Journal of Economics, 118 (November), p. 1209-1248.

Paksi B. - Demetrovics Zs. (2003): A drogprevenciós gyakorlat megismerése: Budapesti iskolai drogprevenciós programok felmérése és értékelése. L'Harmattan Kiadó, Budapest

Rabin, M. (2008): Pszichológia és közgazdaságtan. Alinea Kiadó - Rajk László Szakkollégium, Budapest

Simon, H.A. (1982): Korlátozott racionalitás. Közgazdasági és Jogi Könyvkiadó, Budapest

Cikk beérkezett: 2011. 2. hó

Lektori vélemény alapján véglegesítve: 2011. 4. hó

Függelék
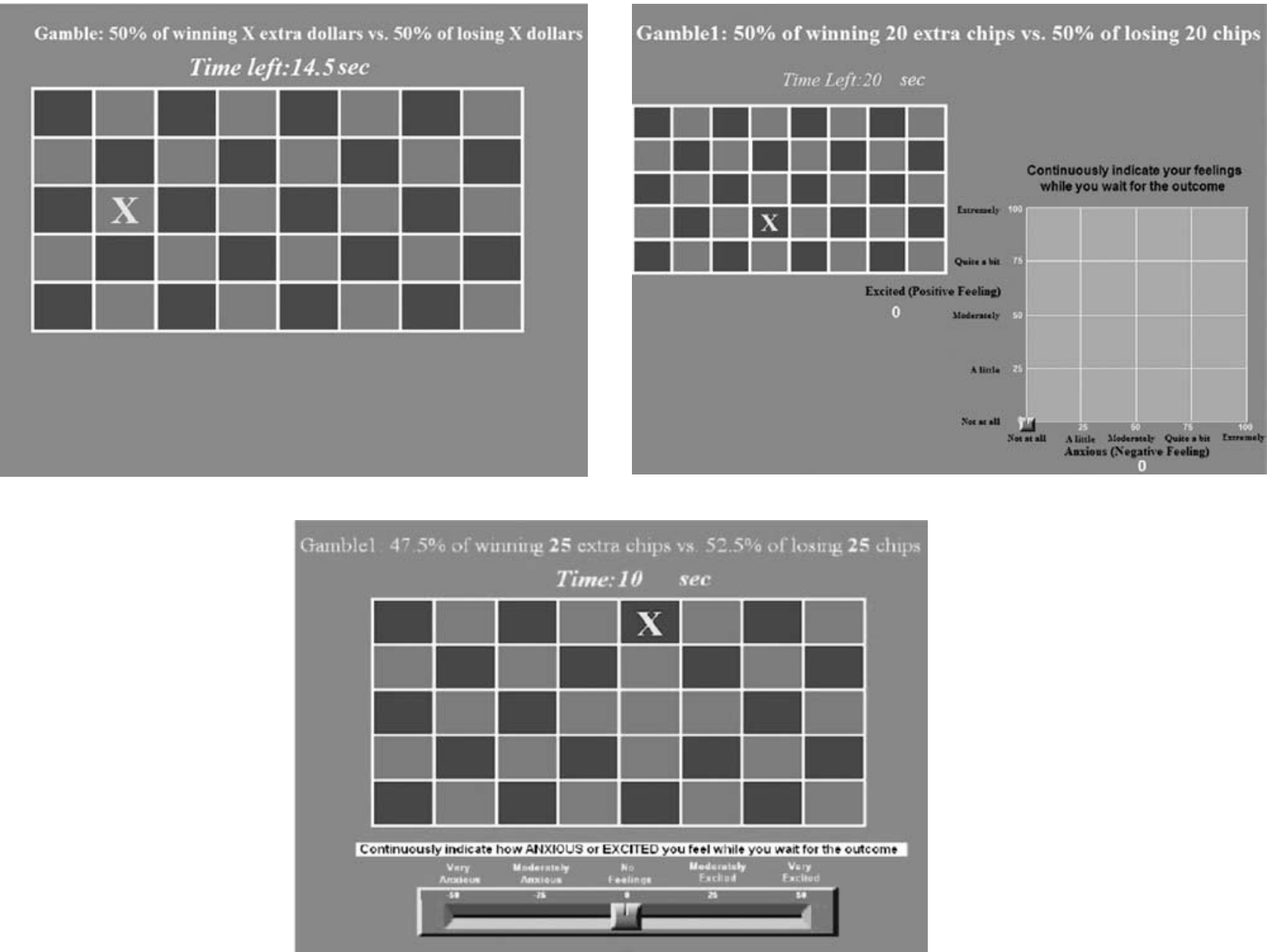

Forrás: Andrade - Iyer: Dynamic Inconsistencies in Gambling and the Role of Feelings (working paper p. 48-49.) 